\title{
Can the bullet train speed up climate change mitigation in China?
}

C The Author (s) 2017. Published by Higher Education Press. This is an open access article under the CC BY license (http:// creativecommons.org/licenses/by/4.0)

Infrastructure systems play a fundamental role in reducing greenhouse gas (GHG) emissions to avert global climate change (Kennedy et al., 2014). Transportations are recognized as one of the key factors for facilitating climate change mitigation (Shaw et al., 2014). Approximately 19\% of global energy consumption and $23 \%$ of energy-related carbon dioxide $\left(\mathrm{CO}_{2}\right)$ emissions come from the transportation sector (IEA, 2012). The demands are still increasing at an annual average rate of $1.4 \%$ (EIA, 2016). Scholars have called for low-carbon infrastructure investments as a solution to foster climate mitigation (Creutzig et al., 2015), but the effects of such investments should be deliberately estimated in tandem with the specific conditions, constraints, and opportunities. This is especially required for China's ambitious bullet train (BT) program.

China has the world's longest BT network with over $22,000 \mathrm{~km}$ of track in service at the end of 2016. The record is still being reclaimed each day, leaving everyone else in the dust. Although the introduction of BTs promotes market integration and mitigate the cost of megacity growth (Zheng and Kahn, 2013), the grand engineering scheme may come at the price of negative environmental impact during its construction (Haddad, 2015). More controversially, some environmentalists claim that BT is environmentally beneficial and should be allowed to form an important part of climate change mitigation (Westin and Kågeson, 2012). Propelled by electricity, the BT looks likely to be an efficient transport scheme for reducing $\mathrm{CO}_{2}$ emissions, but the outcome may be quite different to the rose-colored expectation. To make a full assessment of the net climate benefits, a life cycle perspective must be

Han LIN, Shilong GE, Yongtai CHEN

School of Engineering Management, Nanjing Audit University, Nanjing 211815, China

Saixing ZENG (ه)

Antai College of Economics \& Management, Shanghai Jiao Tong University, Shanghai 200030, China

E-mail: zengsaixing@sjtu.edu.cn applied including the embedded indirect emissions and pollution during the construction and operation periods as well as the closure and reclamation (Rooney et al., 2015).

First, the BTs' emission reduction is dependent on $\mathrm{CO}_{2}$ embedded throughout the whole life-cycle of engineering projects. The spread of BT network consumes stunning quantities of cement and steel, which are produced by coaldriven industries with overcapacity, poor profit, and low technology. The high energy intensity in raw material production engenders substantial emissions during constructing and maintaining phases (Westin and Kågeson, 2012). The reduced car or truck traffic owing to BTs could reduce the need for road investment and maintenance. However, it is difficult to assess the amount of road building that would be avoided by building the high-speed line (Akerman, 2011). In practice, BT routes comprise a large number of bridges and culverts. For example, the Beijing-Shanghai BT Line has 288 bridges, 1074 kilometers in length, which account for $81.5 \%$ of the total length. This kind of design pattern would consume heavier stuff. The potential investment bubble would increase significant $\mathrm{CO}_{2}$ emissions, let alone the severe environmental degradation induced by these corridors for people (Haddad, 2015).

Second, the BTs' emission reduction falls back on energy structure. As coal has long been the dominant source of energy in China, the carbon intensity of electricity generation in China is quite high and electricity production is itself a substantial direct source of global GHG emissions (Kennedy, 2015). Although China stated its intention to increase the share of non-fossil fuels in primary energy consumption to around $20 \%$ by 2030 (Lewis et al., 2015), hydropower, wind, and nuclear generation are not cost competitive at present. Resilience of electricity grids, congestion, and costs are also big challenges. Losses in the grid from power plant to trains (catenary system) amount to about 4\% (Åkerman, 2011). The BTs' advantages over internal combustion engines would be greatly discounted, due to the coal-based energy 
structure. Speed is also a critical factor. Energy consumption is correlated to the square value of the BT speed. The higher speed, the more GHG emissions are produced. Optimized schedules should be deployed to achieve the goal of low emissions per passenger kilometer. With the development of technology, alternative green vehicles will play their roles in urban mobility. The evolving scenario should be considered with the discreet scrutiny against fantastic feats and intuitive thinking.

Third, the BTs' emission reduction would be offset by the travel mode shift. Passenger transportation is expected to account for an increasingly important fraction of future energy use and $\mathrm{CO}_{2}$ emissions (Girod et al., 2013). Passengers' preference for luxury level, and environmentally motivated changes like shifting preference for transport modes and increasing vehicle occupancy will lead to new travel behavior patterns. In response to external drivers, these new patterns shape the extent that fuels substitution and transportation systems. Theoretically, the less travel by air and car, the more emissions reduced. However, despite the fact that the new BT lines provide a relatively lower travel cost, they would also attract substantial additional travel that shifts from less energy intensive walking and cycling towards more energy intensive modes. When travel demand, especially in the areas with low population density, is rising steeply, its contribution to global $\mathrm{CO}_{2}$ emissions is increasing.

To tackle climate change in the aftermath of the Paris climate deal, China needs to deliberately scrutinize its grand transportation infrastructure programs if it is to alleviate rampant pollution. Additional carbon policies, such as fuel economy standards and labeling, vehicle and fuel taxation, could help reduce the sector's energy consumption and $\mathrm{CO}_{2}$ emissions by reducing service demands, and help modal shifts towards less energy intensive technologies and less carbon intensive fuels (Yin et al., 2015). Moreover, a synergy among the public transport systems, the transformation of dirty industries, and the growth of green trip would likely remove the roadblock and give China the clean bill it is striving for, rather than the explosive development of BTs.

Acknowledgements This research was supported by the National Natural Science Foundation of China (Grant No.71390525).

\section{References}

Åkerman J (2011). The role of high-speed rail in mitigating climate change - the Swedish case Europabanan from a life cycle perspective. Transportation Research Part D, Transport and Environment, 16 (3): 208-217

Creutzig F, Jochem P, Edelenbosch O, Mattauch L, Vuuren D P, McCollum D, Minx J (2015). Transport: a roadblock to climate change mitigation? Science, 350(6263): 911-912

EIA (2016). International Energy Outlook 2016. U.S. Energy Information Administration, Washington, DC, USA

Girod B, van Vuuren D P, de Vries B (2013). Influence of travel behavior on global $\mathrm{CO}_{2}$ emissions. Transportation Research Part A, Policy and Practice, 50(4): 183-197

Haddad N M (2015). Corridors for people, corridors for nature. Science, 350(6265): 1166-1167

IEA (2012).World Energy Outlook 2012.International Energy Agency, Paris, France

Kennedy C A (2015). Key threshold for electricity emissions. Nature Climate Change, 5(3): 179-181

Kennedy C A, Ibrahim N, Hoornweg D (2014). Low-carbon infrastructure strategies for cities. Nature Climate Change, 4(5): 343-346

Lewis J I, Fridley D G, Price L K, Lu H, Romankiewicz J P (2015). Understanding China's non-fossil energy targets. Science, 350 (6264): 1034-1036

Rooney R C, Robinson D T, Petrone R (2015). Megaproject reclamation and climate change. Nature Climate Change, 5(11): 963-966

Shaw C, Hales S, Howden-Chapman P, Edwards R (2014). Health cobenefits of climate change mitigation policies in the transport sector. Nature Climate Change, 4(6): 427-433

Westin J, Kågeson P (2012). Can high speed rail offset its embedded emissions? Transportation Research Part D, Transport and Environment, 17(1): 1-7

Yin X, Chen W, Eom J, Clarke L E, Kim S H, Patel P L, Yu S, Kyle G P (2015). China's transportation energy consumption and $\mathrm{CO}_{2}$ emissions from a global perspective. Energy Policy, 82(1): 233-248

Zheng S, Kahn M E (2013). China's bullet trains facilitate market integration and mitigate the cost of megacity growth. Proceedings of the National Academy of Sciences of the United States of America, 110(14): E1248-1253 